\title{
BRAND VALUATION FROM THE BALANCE SHEET LAW PERSPECTIVE
}

\author{
Katarzyna Petelska \\ Warsaw School of Economics
}

\begin{abstract}
Aim of the article is to discuss arguments for and against recognition of internally created brands in the company's financial statements. The author discusses definitions and functions of brand as well as valuation approaches in order to assess possibilities of reliable measurement of a brand's carrying value in the balance sheet. The article also presents results of review annual financial statements of companies listed on the Warsaw Stock Exchange and included in WIG 30 index. The review was conducted to find out if the companies disclose brands in their financial statements, and if so, how the brands were originated and how their value is determined.
\end{abstract}

Keywords: accounting, brand valuation, balance sheet recognition

\section{JEL Codes: M41}

\section{Introduction}

Brand is one of intangible assets and plays an important role for companies and financial institutions. According to consulting firms specialising in brand valuation the top global brands are worth hundred million dollars. If a brand is created internally and not acquired, then according to balance sheet law, the costs incurred to build it are presented in financial statements as an expense on accrua basis and cannot be capitalised i.e. recognised as an asset in the balance sheet. Aim of this article is to review the existing brand valuation approaches in order to analyse if they can be used for estimating carrying value of a brand and to try to answer a question if a change of current accounting approach to the internally created brands would be justified. The arguments presented have been illustrated by a review of the Polish market practise in this area.

\section{Brand and its definitions}

Literature gives many definitions of a brand. Altkorn (1998) indicates that the word „brand” can be understood at least threefold:

1. brand as indication of certain products, lines of products or the whole range of products offered by a company;

2. brand as a synonym of a trade mark in the legal literature and legal acts;

3. brand as a way of simple, judgmental expression of an image of a product, a set of products and/or the organization that offers them (Altkorn, 1998, p. 11-12 in WitekHajduk, 2001, p. 23).

Kotler (1994) agrees with a definitione given by the American Marketing Association, i.e. "brand is a name, term, design, symbol, or a combination of them, intended to identify the goods or services of one seller or group of sellers and to differentiate them from competitors." (Kotler, 1994, p. 41 in Witek-Hajduk, 2001, p. 23). Urbanek (2002) adds that the brand indicates origins of the goods or services to the buyer and protects the customer and producers from competitors who could potentially offer identical products. He underlines that brand can be treated as a seller's obligation to constantly deliver a set of features, benefits and services together with the product labeled with the particular brand (Urbanek, 2002, p.14). According to this author, a brand has a leading position among intangible assets from the point of view 
of both the current and future ability of a company to create value (Urbanek, 2008, p. 44). This opinion is consistent with the original meaning of the word "brand", namely to "burn". As Witek-Hajduk (2001) claims after Murphy (1991), it comes from the times when ,the first cattle breeders in the areas of current United States of America used to mark their herds with the glowing iron. Marking animals was the prerequisite for the maintenance of the market as a sign burned allowed to determine the origin of animals (also in case of theft), as well as informed about the quality" (Murphy 1991, p. 2 in Witek-Hajduk, 2001, p. 26). However, the history of a brand is much longer as it dates back to the acient times. Already then the craftsmen of the Middle East, Rome, Greece or China marked their pottery, jewelry or art pieces with their name or sign, which on one hand distinguished them from competitors and on the other hand worked as a guarantee of quality. (Witek-Hajduk, 2001, p. 15-18) With the passing of time, when first craftsmen' guilds and first companies were established, importance of brands was growing and it began more visibly to fulfill three functions: identification, quarantee and promotion.

Identification is believed to be the basic function as it stems directly from the brand substance (Witek-Hajduk, 2001, p. 31). Guarantee function means that using a brand obliges its owner to a defined level of "guaranteed" quality maintained constantly in a long term (WitekHajduk, 2001, p. 32). The last of the above mentioned functions, i.e. promotion, comes from the possibility of using a brand as a tool of communication with existing and prospective customers. Brand became a marketing tool enabling to:

- strengthen differentiation of product (offer) through offering emotional benefits attached with a brand,

- limit a scope of product substitution,

- protect from being imitated by competitors,

- build barriers for competitors entering the industry (loyalty barier),

- increase bargaining power against suppliers (which makes it easier to achieve brand owner's goals)

- have more freedom in setting product price (Taranko, Chmielewski, 2014, p.133-134).

Urbanek (2002) perceives a brand as a strategic resource of a company and believes that it constitutes the only asset which can remain unchanged for many years and, if properly protected, cannot be copied" (Urbanek, 2002, p. 9).

Some companies spend substantial amounts of money on building its brand (eg. TV and radio advertisements, promotional campaigns, special events) According to the current accounting rules, in line with prudence concept all these spendings are treated as costs thus decrease financial results of the current period, while their long-term, potentially positive effect on future financial results is not visible. If Management Board took into account only accounting perspective and financial results of the current period, it could decide to limit or even cease spendings on brand building which could adversly influence long-term competitive advantage of the company. The fact that acquired brands according to IAS 38 and the Polish Accounting Act are recognised in balance sheet (statement of financial position) makes the situation even more complicated. In particular, it undermines comparability between companies that decided to build brands internally and those that bought it and also it may give rise to intergroup transactions which aim at bringing the internally created brands into the standalone financial statements of group companies. Case study on LPP Group conducted by Grzybek (2015) explains this mechanism and analyses how it impacts the picture of the company's financial situation.

In this situation, attempts are being made to find a way to measure brand value reliably and to 
include it in a balance sheet, despite of the fact that the brand was built internally.

\section{Brand valuation approaches}

Urbanek (2008) states that "in case of a brand valuation one measures the excess gains obtained by the entity thanks to marking its goods with a brand over the gains that would have been earned if the goods sold had no brand" (Urbanek, 2008, p. 156). There are three main valuation approaches: the cost approach, the market approach and the income approach.

The cost approach identifies costs that would have to be incurred to replace or reproduce a brand. The weakness of this approach lies in its assumption that the brand is worth exactly the money that was spend to build it while firstly, in reality a part of costs could have pertained to something eg. promotional campaigns of a certain product and not a brand as a whole. Secondly, cost spent not necessarily increase value of the brand, efforts made can as well fail.

According to the income approach, a brand value can be derived from analysis of the branddriven income generated in the past and estimation of respective future income. Among the income approaches one can distinguish the following methods: discounted cash flows method, licence fees method (Relief from Royalty) and multiplier method (Góralski, 2013, p. 163).

The market approach uses prices observed in market transactions of buying and selling a brand similar to the brand that is subject to valuation. Adjustments are made, if necessary, to reflect specific features of the valued brand. Góralski (2013) claims that "underlying assumptions of this approach are its biggest weakness, since the following conditions need to be met for the approach to be applied:

- existence of an active market for similar transactions,

- access to the detailed terms and conditions of transactions made together with a description of the brand features to enable comparison,

- recent history of transactions to which the valuation refers and lack of significant changes in market conditions since then (Góralski, 2013, p. 163).

Another market approach, called the economic product value, tries to divide the price paid into two components: an actual value of the product deriving from its features and additional amount of money paid because of the brand.

Worldwide, as well as in Poland, there are consulting firms specialising in brand valuation which prepare annual brand rankings. Such companies are: Interbrand, Millward Brown Interbrand, Millward Brown Optimor (BrandZ list), European Brand Institute in Vienna, Brand Finance, Global Finance and other (Duguleana, Duguleana, 2014, p. 43). These firms usually deal with well-known global brands. In Poland, various local brand rankings exist, such as "The most precious brands" published by a daily newspaper Rzeczpospolita since 2006, „10 most precious brands in Poland" published by a monthly magazine Wprost, „Trustworthy brand” listing of a magazine „My Company Polska” prepared based on a research carried out by Millward Brown institute, "Top Brand" listing prepared by Press magazine and Press Service Media Monitoring or plebiscite "Global Poland" initiated by Business Magazine Manager.

Because of the different approaches and methods used, values of the same brands, in the same period of time, can differ significantly depending on the authors of the ranking.

Table 1. presents examples of such discrepancies. 
Table 1. Brand values based on 2016 reports prepared by Millward Brown and Brand Finance (amounts in USD mln)

\begin{tabular}{|r|l|c|c|c|}
\hline No. & Brand & Millward Brown & Brand Finance & Difference in USD mln \\
\hline 1 & Google & 229,198 & 94,184 & 135,014 \\
\hline 2 & Apple & 228,460 & 145,918 & 82,542 \\
\hline 3 & Microsoft & 121,824 & 67,258 & 54,566 \\
\hline 4 & AT\&T & 107,387 & 59,904 & 47,483 \\
\hline 5 & Facebook & 102,551 & 34,002 & 68,549 \\
\hline 6 & amazon.com & 98,988 & 69,542 & 29,446 \\
\hline 7 & Marlboro & 84,143 & 29,935 & 54,208 \\
\hline 8 & Coca-cola & 80,314 & 34,180 & 46,134 \\
\hline 9 & IBM & 86,206 & 31,786 & 54,420 \\
\hline 10 & China Mobile & 55,923 & 49,810 & 6,113 \\
\hline
\end{tabular}

Source: own compilation based on [www4, www5]

To address this issue, International Organization for Standardization prepared and issued ISO 10668 standard "Brand Valuation". Its purpose is to provide a consistent and reliable approach to brand valuation (www2, www3). The standard describes six steps of brand valuation:

- step 1: definition of the brand that has been valued

- step 2: purpose of the valuation

- step 3: premise of value

- step 4: selection of the valuation approach and method

- step 5: assumptions and analysis

- step 6: valuation report.

The topic has been also dealt with by The International Valuation Standards Council ${ }^{1}$, chaired by Sir David Tweedie, former long-term chairman of The International Accounting Standards Board. IVSC issued in 2010 International Valuation Standard No. 210 „Intangible Assets” which followed the Guidance Notes No. 4 "Valuation of Intangible Assets". IVS 210 gives an overview of intangible assets, valuation approaches and methodologies. The fact that the above mentioned standards have been issued indicates a pursuit to provide a high quality valuations of intangible assets and also to regulate the area and thus enhance its reliability.

\section{Brand from accounting perspective}

In the literature you can find a statement that brand, as well as other intangible assets, is not properly recognised in the financial statements, and more specifically in the balance sheet statement, which impairs quality of information provided by the accounting system (Wasserman, 2015). Bareja (2015) states „intangible assets, despite being company's key success factors, are reported in the financial statements only to a limited extent. This causes dissatisfaction among those who support broader disclosures on intangible assets. They claim that since accounting does not present key resources it cannot meet the demands of the knowledge based economy" (Bareja, 2015, p. 222). The author lists further allegations

\footnotetext{
1 The International Valuation Standards Council (IVSC) is an independent, not-for-profit organisation that produces and implements universally accepted standards for the valuation of assets across the world in the public interest. It gathers valuer's organisations from 45 countries including e.g. The Polish Federation of Valuer's Associations as well as a number of other institutions from around the world, such as Institute of Chartered Accountants in England and Wales. Source: (www1).
} 
against accounting, such as: a growing dissonance between company's carrying value and its market value, incomplete information on its assets, assymetry of information between entities whose operations are driven by tangible assets (e.g. heavy industry, transportation, oil and mining companies) and those, whose strengths lay in intangible assets (such as media houses, universities, publishing houses, advertising agencies, trade companies, financial institutions etc.). It may lead to understatement of the market value of the latter group and thus result in a higher cost of capital to be paid.

When the matter is looked into from the balance sheet law perspective, two questions need to be asked: does a brand meets definition of an asset? And if so, what should be its value in the balance sheet statement (statement of financial position according to IFRS)?

It is worth reminding that questions about assets' and liabilities' value and scope of the accounting evidence are almost as old as the accounting itself (Lazarowicz, 2011, p. 43).

For many centuries the accounting evidence did not encompass intangible assets and thus its valuation was not a subject of accountants' and enterpreneurs' considerations. Most probably there was no need for that. The situation changed when the ownership structure of entities became more complicated and external financing through banks, stock exchanges, private equity funds etc. became more popular.

At present, the balance sheet law and the accounting standards outline the framework of accounting system and define what can and what cannot be classified as an asset. The standards say that asset is a resource controlled by the entity as a result of past events and from which future economic benefits are expected to flow to the entity and also that it should have either a purchase price or another value that can be reliably measured.

It can be stated that brand is controlled by an entity (e.g. the entity is entitled to sell it or withdraw from the market) and that it was built as a result of past events (efforts made to create it). Doubts arise when it comes to reliable measurement of its value and proving that it actually will rbring the future inflows of economic benefits.

Below, author analyses if the generally accepted approaches to brand valuation, i.e. market approach (fair value), income approach and cost approach can be used as a reliable tool for determining brand carrying value in the balance sheet statement.

The market approach reminds of a very popular fair value measurement. The International Financial Reporting Standard No. 13 "Fair Value Measurement" (IFRS 13) issued by the International Accounting Standards Board in 2011 indicates that objective of the fair value measurement is to estimate the price at which an orderly transaction to sell the asset or to transfer the liability would take place between market participants at the measurement date under current market conditions.

IFRS 13 gives the highest priority to quoted prices in active markets for identical assets or liabilities at the date of valuation. However, it permits also other techniques of fair value estimation, introducing the following hierarchy: 
Table 2. Fair Value Hierarchy.

\begin{tabular}{|c|c|c|}
\hline Level 1 inputs & Level 2 inputs & Level 3 inputs \\
\hline $\begin{array}{l}\text { Quoted prices (unadjusted) in } \\
\text { active markets for identical assets } \\
\text { or liabilities that the entity can } \\
\text { access at the measurement date. } \\
\text { A quoted price in an active market } \\
\text { provides the most reliable evidence } \\
\text { of fair value and shall be used } \\
\text { without adjustment to measure fair } \\
\text { value whenever available. }\end{array}$ & $\begin{array}{l}\text { Inputs other than quoted prices } \\
\text { included within Level } 1 \text { that are } \\
\text { observable for the asset or } \\
\text { liability, either directly or } \\
\text { indirectly, such as: quoted prices } \\
\text { for similar assets or liabilities in } \\
\text { active markets, quoted prices for } \\
\text { identical or similar assets or } \\
\text { liabilities in markets that are not } \\
\text { active. As a rule these inputs } \\
\text { needs adjustments. }\end{array}$ & $\begin{array}{l}\text { Unobservable inputs shall be used to } \\
\text { measure fair value to the extent that } \\
\text { relevant observable inputs are not } \\
\text { avail-able, thereby allowing for } \\
\text { situations in which there is little, if } \\
\text { any, market activity for the asset or } \\
\text { liability at the measurement date. } \\
\text { Unobservable inputs shall reflect the } \\
\text { assumptions that market participants } \\
\text { would use when pricing the asset or } \\
\text { liability, including assumptions about } \\
\text { risk. }\end{array}$ \\
\hline
\end{tabular}

Source: own compilation based on IFRS 13

Since a brand is not a standard quoted commodity available on any market, and what's more finding similar markets transactions would be a challenging task, its fair value would have to be categorised as the third, least objective level of fair value.

Under income approach value of an asset is established using the future expected cash flows, whose amounts and dates are usually scheduled in an agreement with a client. The cash flows might be adjusted using the valuer's professional judgement, based on similar transactions in tha past or a history of cooperation with this or similar clients. However, the expected cashflow generated by the brand are only forecasted future sales inflows, and are influenced by numerous different factors other than the brand.

The cost approach measures value of a brand based on the historic costs incurred to build a brand. For the costs to be treated as an estimation of the brand's carrying value, it would be crucial to distinguish between the costs that can be assigned to the brand creation and the costs that should be assigned to other marketing activities. The fact that usually a broad range of undertakings plays a role in brand creation, hinders performing of this task.

Emerling and Grzybek (2016) note that "existence of such many different brand valuation methods make it difficult to measure its initial value and by using various approaches one can end up with very different values. Additionally, all the methods require making a number of assumptions regarding future, which are highly subjective and prone to manipulations".

If an entity recognizes a brand in the balance sheet, then it is required to determine its economic useful life and the adequate amortization method. According to IAS 38 an entity shall assess whether the useful life of an intangible asset is finite or indefinite and, if finite, the length of that useful life. An intangible asset shall be regarded by the entity as having an indefinite useful life when, based on an analysis of all of the relevant factors (economical and legal), there is no foreseeable limit to the period over which the asset is expected to generate net cash inflows for the entity. An intangible asset with a finite useful life is amortised and an intangible asset with an indefinite useful life is not. Additionally, the useful life of an intangible asset that arises from contractual or other legal rights shall not exceed the period of the contractual or other legal rights, but may be shorter depending on the period over which the entity expects to use the asset. If the contractual or other legal rights are conveyed for a limited term that can be renewed, the useful life of the intangible asset shall include the renewal period(s) only if there is evidence to support renewal by the entity without significant cost. This factor is crucial especially in case of determining the useful life of the registered trademarks.

The standard requires that the useful life was reviewed at least at each financial year-end in 
case of assets with a finite useful life, and each period in case of assets with indefinite useful life. If the events and circumstances do not support an indefinite useful life assessment anymore, the change in the useful life assessment from indefinite to finite shall be accounted for as a change in an accounting estimate in accordance with IAS 8 "Accounting policies, changes in accounting estimates and errors". In accordance with IAS 36 "Impairment of assets" (IAS 36), reassessing the useful life of an intangible asset as finite rather than indefinite is an indicator that the asset may be impaired. As a result, the entity tests the asset for impairment by comparing its recoverable amount, determined in accordance with IAS 36, with its carrying amount, and recognising any excess of the carrying amount over the recoverable amount as an impairment loss. For the intangible assets with a finite useful life, their depreciable amount shall be allocated on a systematic basis over its useful life and ceased only if the brand is classified as held for sale (or included in a disposal group that is classified as held for sale) in accordance with IFRS 5 "Non-current assets held for sale and discontinued operations" and the date that the asset is derecognised. The amortisation method used shall reflect the pattern in which the asset's future economic benefits are expected to be consumed by the entity. If that pattern cannot be determined reliably, the straight-line method shall be used. The amortisation charge for each period shall be recognised in profit or loss. Although the standard gives an option to treat the amortization charge as a part of the cost of another asset, it can be stated that this is rather difficult to find such circumstances that would justify treating an amortization charge of a brand as a part of the inventories.

\section{Brand in the financial statements of WIG 30 companies.}

WIG 30 index comprises of companies quoted on the Warsaw Stock Exchange, representing the following industries: banking (7), developers (1), energetics (4), retail trade (3), IT (2), media (1), chamicals (2), oil and gas (3), food (1), basic materials (3), telecom (1), insurance (1) and other services (1).

Review of their annual financial statements as of 31.12.2015 (www7, www8, www9, www10, www11, www12, www13, www14) showed that eight of them recognise brands or trade marks within intangible assets, these are: Alior Bank, Asseco Poland, CD Projekt, Cyfrowy Polsat, Eurocash, LPP, PZU and Synthos. Two other mention trade marks without giving their details. Another one informs about paying fees for using a corporate brand.

Out of the eight entities that present brands or trade marks:

- seven recognised the assets through an acquisition of another company or a merger within the group companies, one did not provide explanations on that subject,

- six companies use Relief from Royalty method to value their brands and trade marks, two did not provide explanations,

- five estimated that economic useful life of their brands or trade marks is indefinite and instead of being depreciated the assets are tested annually for impairment, except for one brand which is amortised on a straight-line basis for a period of 51 years; three companies did not provide detailed disclosures on depreciation method nor estimated economic useful life,

- six described their accounting policies on brands and/or trade marks, but only four of them explained how they estimate their initial carrying value.

Detailed findings are presented in Appendix 1.

Based on the above it can be concluded that in the most cases trade marks and brands were originated as a result of acquisition or merger of related companies. Despite various approaches available, WIG 30 companies most often use the Relief from Royalty method to measure value of its brands and trademarks. Also, a common approach can be observed with 
regards to estimation of economic useful life as indefinite and conducting annual test for impairment.

\section{Summary}

Recognition of brand as well as other intangible assets in the balance sheet statement (statement of financial position) is an interesting and relevant topic for both theorists and practitioners of accounting and marketing. Current balance sheet law approach is being criticised however any quick changes are hindered by material issues relating to measurement of the assets' carrying value. The question how to find an optimal solution without giving up on high quality and credibility of accounting system, remains unanswered. Would a new type of a financial statement be such a solution or should we rather focus on finding possibilities to reliably measure brand value and recognise it in the existing financial statements, it will be most probably a subject of researches conducted in the near future. The researchers might find inspiration in the arising market practice. At the moment we can conclude that lack of proper regulation of this important business matter in the balance sheet law may encourage creative (in a negative sense) reporting practices that are difficult to reveal (in the course of audit process).

\section{References}

Bareja K. (2015). Aktywa niematerialne a priorytet w sprawozdawczości finansowej. Research Papers of Wroclaw University, no. 388. Wroclaw.

Duguleana L., Duguleana C., Brand Valuation Methodologies and Practise. (2014). Bulletin of the Transilvania University of Braslov Series V: Economic Sciences Vol. 7 (56), no. 1.

Emerling I., Grzybek O. (2016) Wpływ wyceny znaków towarowych na wynik finansowy podmiotu gospodarczego. Zeszyty Naukowe Uniwersytetu Ekonomicznego w Katowicach No. 253, Katowice.

Góralski B. (2013). Wycena marki metodą Brand-driven Earnings. Wroclaw, Research Papers of Wroclaw University No. 291.

Grzybek O. (2015). Wykorzystanie wartości niematerialnych w transakcjach przeprowadzanych wewnątrz grupy kapitałowej do realizacji celów polityki rachunkowości przedsiębiorstw. Zeszyty Naukowe Uniwersytetu Ekonomicznego w Katowicach No. 224, Katowice.

Łazarowicz E. (2011). Historia powstania księgowości podwójnej i rachunku kosztów. Oficyna Wydawnicza SGH, Warsaw, Monografie i opracowania No. 579.

Taranko T., Chmielewski K. J. (2014). Brand as a Source of Value for Its Buyer and Owner, Management and Business Administration. Central Europe, vol. 22, No. 4 (127), Warszaw, pp. 133-143.

Urbanek G. (2008). Wycena aktywów niematerialnych przedsiębiorstwa. Warsaw: PWE.

Urbanek G. (2002). Zarządzanie marką. Warsaw: PWE.

Witek-Hajduk M. (2001). Zarządzanie marką. Warsaw Difin.

Conceptual Framework for Financial Reporting issued by International Accounting Standards Board,

International Accounting Standard No. 38 and International Financial Reporting Standard No. 13 issued by the Regulation of European Commission no. 1126/2008 of 3 November 2008 (Official Journal No. L 320 of 29.11.2008) with subsequent amendments. 
Polish Accounting Act of 29 September 1994 (Journal of Laws 1994 No. 121 item 591) with subsequent amendments.

[www1] Description of the International Valuation Standards Council in the section „About us" available on line at: http://www.ivsc.org (accessed 8.05.2016)

[www2] Overview of the ISO Standard No. 10668 given by International Organization for Standarisation available on line at: http://www.iso.org (accessed 8.05.2016)

[www3] Overview of the ISO Standard No. 10668 given by Brand Finance available on line at http://brandfinance.com/images/upload/iso_10668_overview.pdf (accessed 10.05.2016)

[www4] Brand Finance, raport 2016 available on line at: http://brandfinance.com/knowledgecentre/reports/brand-finance-global-500-2016/ (accessed 19.06.2016)

[www5] Millward Brown, raport 2016

available on line at: http://wppbaz.com/admin/uploads/files/BZ_Global_2016_Report.pdf (accessed 19.06.2016)

[www6] B. Wasserman, Valuation of Intangible Assets: Should Brand Equity Be Accounted for on the Balance Sheet? Honors Scholar Thesis, Paper 411, University of Connecticut, 2015 available on line at:

http://digitalcommons.uconn.edu/cgi/viewcontent.cgi?article $=1448 \&$ context=srhonors_theses (accessed 8.05.2016)

[www7] Financial statements of Alior Bank SA as at and for the year ended 31 December 2015 available on line on: aliorbank.pl (access 8.08.2016)

[www8] Financial statements of Asseco Poland SA as at and for the year ended 31 December 2015 available on line on asseco.pl (accessed 8.08.2016)

[www9] Consolidated financial statements of CD Projekt Capital Group in the fiscal year 2015 available on line on cdprojekt.com (accessed 8.08.2016)

[www10] Cyfrowy Polsat SA Capital Group annual report for the financial year ended December 31, 2015 available on line on: grupapolsat.pl (accessed 9.08.2016)

[www11] Eurocash separate annual report for the 2015 available on line on: eurocash.pl (accessed 9.08.2016)

[www12] Consolidated annual report of LPP Capital Group for 2015 available on line on: lppsa.com (accessed 9.08.2016)

[www13] The annual report of PZU SA for 2015 available on line on: pzu.pl (accessed 9.08.2016)

[www14] Synthos S.A. consolidated annual report for the period from January 1st 2015 to December 31st 2015 available on line on: synthosgroup.com (accessed 9.08.2016) 


\section{Appendix 1}

Table 1. Trade marks and brands disclosed by WIG 30 companies in the annual financial statements as of 31.12.2015 (amounts given in PLN thousand, unless otherwise stated).

\begin{tabular}{|c|c|c|c|c|}
\hline \multirow{3}{*}{$\begin{array}{l}\text { Attribute } \\
\text { of } \\
\text { analysis }\end{array}$} & \multicolumn{4}{|c|}{ Name of the company/Type of financial statements } \\
\hline & Alior Bank & Asseco Poland & CD Projekt & Cyfrowy Polsat \\
\hline & standalone & standalone & standalone & consolidated \\
\hline A1. & $\begin{array}{l}\text { "Meritum Bank" } \\
\text { trade mark }\end{array}$ & "Asseco" trade mark & $\begin{array}{l}\text { corporate brand "CD } \\
\text { Projekt", "The Witcher" } \\
\text { trade mark }\end{array}$ & $\begin{array}{l}\text { brands: Plus, Polsat, } \\
\text { TV4, TV6, Ipla }\end{array}$ \\
\hline A2. & $\begin{array}{l}\text { acqusition of } \\
\text { Meritum Banku }\end{array}$ & $\begin{array}{l}\text { merger of Softbank and } \\
\text { Asseco Poland }\end{array}$ & $\begin{array}{l}\text { merger between group } \\
\text { companies }\end{array}$ & $\begin{array}{l}\text { acqusition of } \\
\text { subsidiaries }\end{array}$ \\
\hline A3. & $300^{*}$ & 137.600 & 18.364 & $2,080,600$ \\
\hline A4. & Relief from Royalty & no data & Relief from Royalty & Relief from Royalty \\
\hline A5. & no data & indefinite & no data & $\begin{array}{l}\text { indefinite except for } \\
\text { "Plus" brand: } 51 \text { years }\end{array}$ \\
\hline A6. & no data & not amortised & no data & $\begin{array}{l}\text { not amortised, except } \\
\text { for "Plus" brand } \\
\text { amortised on a straight- } \\
\text { line basis }\end{array}$ \\
\hline A7. & no data & no data & $\begin{array}{l}\text { information on } \\
\text { valuation method and } \\
\text { annual test for } \\
\text { impairment }\end{array}$ & $\begin{array}{l}\text { information on } \\
\text { estimated economic } \\
\text { useful life, depreciation } \\
\text { method and annual test } \\
\text { for impairment in case } \\
\text { of assets with indefinite } \\
\text { economic useful life }\end{array}$ \\
\hline
\end{tabular}


Table 1 (continued)

\begin{tabular}{|c|c|c|c|c|}
\hline \multirow{3}{*}{$\begin{array}{l}\text { Attribute } \\
\text { of } \\
\text { analysis }\end{array}$} & \multicolumn{4}{|c|}{ Name of the company/Type of financial statements } \\
\hline & Eurocash & LPP & PZU & Synthos \\
\hline & standalone & consolidated & standalone & consolidated \\
\hline A1. & $\begin{array}{l}\text { "Eurocash", "abc", } \\
\text { "Batna" trade marks }\end{array}$ & $\begin{array}{l}\text { "House", "Cropp", } \\
\text { "Reserved" trade marks }\end{array}$ & $\begin{array}{l}\text { "Alior”, „Link4”, } \\
\text { "Lietuvos Draudimas”, } \\
\text { "Aquaform” trade marks }\end{array}$ & no detailed data \\
\hline A2. & $\begin{array}{l}\text { purchase from a } \\
\text { subsidiary }\end{array}$ & $\begin{array}{l}\text { House: merger with a } \\
\text { subsidiary; Cropp, } \\
\text { Reserved: trade marks } \\
\text { transferred as a non-cash } \\
\text { contribution to subsidiaries } \\
\text { established in Cyprus and } \\
\text { United Arab Emirates in } \\
\text { order to execute trade } \\
\text { marks protection rights. }\end{array}$ & acqusition of entities & no data \\
\hline A3. & 295,460 & $\begin{array}{l}\text { House, Mohito and } \\
\text { Sinsay: } 509,570 ; \text { Reserved } \\
\text { and Cropp: } 556.000^{* *}\end{array}$ & $\begin{array}{l}\text { Alior: 100.000, Link4: } \\
\text { 50.000, LD: 19,4 mln } \\
\text { EUR, Aquaform: } 6120\end{array}$ & $\begin{array}{l}64,000 \text { (together with } \\
\text { production know how) }\end{array}$ \\
\hline A4. & Relief from Royalty & Relief from Royalty & Relief from Royalty & no data \\
\hline A5. & $\begin{array}{l}\text { "abc" and "Eurocash": } \\
\text { indefinite, other: 10-20 } \\
\text { years }\end{array}$ & indefinite & indefinite & no data \\
\hline A6. & $\begin{array}{l}\text { "abc" and "Eurocash": } \\
\text { not amortised, other: no } \\
\text { data }\end{array}$ & not amortised & not amortised & no data \\
\hline A7. & $\begin{array}{l}\text { Information that the } \\
\text { initial value of intangible } \\
\text { assets is the acquisition } \\
\text { cost, which includes the } \\
\text { purchase price and other } \\
\text { expenditure directly } \\
\text { attributable to acquiring } \\
\text { the intangible assets, also } \\
\text { information on estimated } \\
\text { economic useful life and } \\
\text { annual test for } \\
\text { impairment in case of } \\
\text { assets with indefinite } \\
\text { economic useful life }\end{array}$ & $\begin{array}{l}\text { Information that the } \\
\text { intangible assets as at the } \\
\text { balance sheet day are } \\
\text { disclosed at the purchase } \\
\text { price, also information on } \\
\text { estimated economic useful } \\
\text { life and annual test for } \\
\text { impairment in case of } \\
\text { assets with indefinite } \\
\text { economic useful life }\end{array}$ & $\begin{array}{l}\text { Information that trade } \\
\text { marks identified during } \\
\text { the acquisition process } \\
\text { are recognized in the } \\
\text { balance sheet at fair } \\
\text { value determined as of } \\
\text { the acquisition date, also } \\
\text { information on estimated } \\
\text { economic useful life and } \\
\text { annual test for } \\
\text { impairment in case of } \\
\text { assets with indefinite } \\
\text { economic useful life }\end{array}$ & $\begin{array}{l}\text { Information that the the } \\
\text { group records acquired } \\
\text { rights to use reserved } \\
\text { trademarks at the cost of } \\
\text { purchase as at the purchase } \\
\text { date and the rights are } \\
\text { amortized over the } \\
\text { estimated period of the } \\
\text { rights' validity. }\end{array}$ \\
\hline
\end{tabular}

A1. Trade mark or brand recognized under „Intangible * Meritum Bank trade mark has been fully Assets"

A2. Origination of the asset

A3. Carrying value (KPLN)

A4. Valuation method

A5. Economic useful life

A6. Depreciation method written off, since 2009 the intangible assets balance amount to $300 \mathrm{k}$ PLN, which was not described in the notes to the financial statements.

** financial statements disclose only the House trade mark worth of $77.508 \mathrm{k}$ PLN, the other amounts presented above were disclosed in a

A7. Information on trade marks and brands disclosued in current report no. 39/2013 on non-cash accounting policies

contributions to Gothals Ltd.

Source: own compilation based on [www7, www8, www9, www10, www11, www12, www13, www14] 